\title{
Effect of Supplementing Cation Anion Salt on Feed Intake during Transition Period in Buffaloes
}

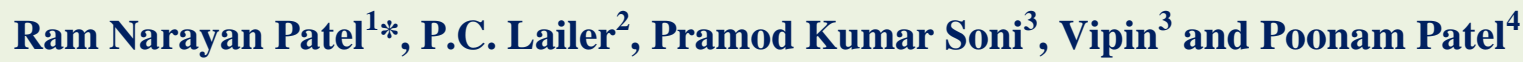 \\ ${ }^{1}$ Livestock production and Management Division, ICAR-National Dairy Research Institute, \\ Karnal-132001, India \\ ${ }^{2}$ Animal Nutrition and Feed Technology Division, ICAR-Central Institute for Research on \\ Buffaloes, Hisar-125001, India \\ ${ }^{3}$ Animal Nutrition Division, ICAR-Indian Veterinary Research Institute, \\ Izatnagar, Bareilly-243122, India \\ ${ }^{4}$ Veterinary Medicine Division, Orissa University of Agriculture and \\ Technology Bhubaneswar- 751003, India
}

*Corresponding author

\begin{abstract}
A B S T R A C T
Keywords

Cation anion salt,

Feed intake,

Transition period

Article Info

Accepted:

17 June 2018

Available Online:

10 July 2018

The effect of feeding prepartum anionic diet and postpartum cationic diet during transition period was studied using twenty pregnant Murrah buffaloes. Commonly available feeds and fodders were analyzed for their $\mathrm{Na}, \mathrm{K}, \mathrm{Cl}$, and $\mathrm{S}$ content to calculate their Dietary Cation Anion Difference value. The buffaloes were divided into two equal groups and were fed with same diet. With that treatment group supplemented -749.16 anion and +1473.56 cation $\mathrm{mEq}$ salt in before and after calving respectively. The treatments were started 21 days before expected date of calving. After parturition, treatment groups were supplemented with extra cationic salt up to 21 days. Prepartum feed intake in both the groups was not affected by dietary treatments. There was significant $(\mathrm{P}<0.05)$ increase in feed intake in treatment group $(12.88 \mathrm{Vs} .11 .60 \mathrm{Kg} /$ day $)$ during postpartum period. The $\mathrm{DM}$ intake/100 $\mathrm{kg}$ body weight was also significant higher $(\mathrm{P}<0.05)$ in treatment group (2.65 Vs. $2.37 \% /$ day) at 21 day after calving. Feed intake increased during postpartum period as compared to prepartum in both the groups of cows.
\end{abstract}

\section{Introduction}

The Transition period is period before and after three to four weeks of calving and this period is very critical for in terms of health, production and reproduction point of view. The periparturient disease conditions are associated with decreased dry matter intake (DMI), and feed intake is a critical determinant of health and productivity in the dry period. Feed intake and nutrient density of the diet determine the availability of nutrients to the cow and rapidly developing foetus. Grant and Albright (1996) reviewed the 
feeding behavior and management factors during the transition period for dairy cattle and found that feed intake decreased by up to $30 \%$ during the week before calving. Factors that influence feed intake include social dominance, digestibility of the diet, access to feed and the palatability of the feed (Grant and Albright 1996).

\section{Materials and Methods}

\section{Location of work}

The present study was conducted at Animal Farm of Central Institute for Research on Buffaloes Hisar Haryana. The entire study comprised of two phases. Phase 1 involved formulation of DCAD diets and Phase 2 comprised of feeding experiment and a total number of 20 buffaloes were divided into two groups of ten each on the basis of equal standard previous lactation milk yield.

Phase 1 Formulation of DCAD based diets for Transition Period:

Calculation of DCAD (mEq/ $\mathrm{kg}$ DM) diet: The percent of minerals $\mathrm{Na}, \mathrm{K}, \mathrm{Cl}$, and $\mathrm{S}$ are measured by AAS and ionomerty IC Plus. In various feeds, cakes, fodders and wheat straw $\%$ values of $\mathrm{Na}, \mathrm{K}, \mathrm{Cl}$ and $\mathrm{S}$ were determined by chemically and some were taken from ICAR Publication book nutrient composition of Indian feeds and fodder and, website of National Institute of Nutrition, Hyderabad for calculation of DCAD.

Estimation of $\mathrm{Na}$ and $\mathrm{K}$ minerals content in Feeds and fodders:

Feed samples were dried in hot air oven at 1000C. Ashing the duplicate feed sample by muffle furnish (temperature $550 \pm 50$ oC). dissolved ash in $25 \mathrm{ml}$ solution ( HCL : D. Water $=50: 50$ ), Than boiled the solution for 5 to 10 minute, than Made solution $100 \mathrm{ml}$ with double distilled water after filtering by
Whatman filter paper with warm water, and subjected for double analysis in Atomic Absorption Spectrometer (AAS), Using the instrument ICE 3300 thermo fisher.

Estimation of $\mathrm{Cl}$ and $\mathrm{S}$ minerals content in Feeds and fodders by Ion Analysis by ionometry (IC Plus):

Sample preparation-Take 1 gram sample, Than dissolve in distilled water (Volume make up $100 \mathrm{ml}$ ) after dry ashing, than filter by Whatman filter paper $(0.46 \mu \mathrm{m})$ and Syringe filter. Minimum sample require is $6 \mathrm{ml}$.

Note- Sample tube should be dipped in sample with syringe aspirate $2 \mathrm{ml}$ sample than press start, than aspirate $3 \mathrm{ml}$ sample, time require 30 minute for every sample. Retention time for chloride (8.8 minute) and for sulphate (23.51 minute).

The $\mathrm{mEq}$ weight ( $\mathrm{mg} \mathrm{x}$ valency/ atomic weight) of the minerals ( $\mathrm{Na}, \mathrm{K}, \mathrm{Cl}$ and $\mathrm{S}$ ) aswell as the dietary cations anions difference (DCAD) value of feeds and fodders were calculated using formula:

$\operatorname{DCAD}(\mathrm{mEq})=(\mathrm{Na}+\mathrm{K})-(\mathrm{Cl}+\mathrm{S})$

The DCAD values of feeds and fodders used for feeding to the buffaloes during transition periods are presented in Table 2, 3 and 4.

Twenty buffaloes were divided into two groups of ten each on the basis of equal standard previous lactation milk yield. Grouping of buffaloes on the basis of previous standard lactation milk yield is given in table 5. Standard milk yield was statistically $(\mathrm{P}>0.05)$ non-significant in both the groups.

\section{Feeding and feed intake recording}

Twenty post-partum high yielding buffaloes maintained at Animal farm of ICAR-Central Institute for Research on Buffaloes were 
selected for the present study. These buffaloes were selected on the basis of previous lactation milk yield (305 day lactation yield) into two groups of 10 animals in each group (Table 5). One group was kept on farm feeding management (control group) and another group was kept on the supplementation of anion salt (-749.16) with normal feeding 21 days before expected date of calving to up to calving (Table 2) and after calving started supplementing cation salt (+1473.56 me) upto 21 days of calving schedule (treatment group) practice of the farmer (Table 4). During test Feed intake of the individual animal was recorded twice in a week and mean of both days was taken for calculation. Exact weight of feeds offered and residual left was recorded. Representative samples were subjected to dry matter estimation for calculation of dry matter intake.

\section{Sampling of feed, fodder, and residue left}

During the experimental period fresh samples of wheat straw, concentrate mixture, sorghum silage and green fodder were collected which offers to the animals. The selected samples were transferred to clean and dry polyethylene bags, brought to the laboratory for dry matter estimation and subsequently for proximate analysis. The residue of feed left weekly by individual animals was also collected and weighed and brought to the laboratory for dry matter estimation. The samples of feed offered and residue left was kept in hot air oven at 100 ${ }^{0} \mathrm{C}$ for 24 hours or till a constant weight was obtained.

\section{Dry matter}

A representative sample of feed ingredients was weighed in moisture cup and kept overnight in a hot air oven at $100{ }^{\circ} \mathrm{C}$. Dried samples were weighed and DM calculated as follows.
$\mathrm{DM}(\%)=$

Weight of the sample after oven drying Fresh weight of the sample

\section{Results and Discussion}

The results of experiments conducted during transition period buffaloes to study the effect of supplementing 90 gram anion salt (-749.16 $\mathrm{mEq}$ ) from -21 days up to calving and after calving started supplementing with 125 gram cation salt (Sodium bicarb. $+1473.56 \mathrm{mEq}$ ) salt up to 21 days of calving on feed intake are presented in this section.

Table 6 shows the daily net $\mathrm{mEq}$ intake by the experimental buffaloes in different groups. Net $\mathrm{mEq}$ intake was 729.79 and -35.79 in control and treatment groups respectively. The -vemEq intake in treatment group before calving was because of 90gram anion salt supplementation 21 days before calving to till calving. After calving buffaloes of treatment group were fed with 125 gram daily cation salt (Sodiunbicarb). The net $\mathrm{mEq}$ intake in treatment group was +ve higher in treatment group in comparison to control group. This was due to supplementation of treatment group with cation salt.

\section{Effect on dry matter intake}

During start of feeding experiment of 21 days before calving DMI $\mathrm{kg} /$ day control and treatment were $11.65 \mathrm{~kg}$ and $11.32 \mathrm{~kg}$ respectively. No significant $(\mathrm{P}>0.05)$ difference was observed in DMI intake between the two groups. Similarly no significant $(\mathrm{P}>0.05)$ difference was observed between the control and treatment group at 7 days before calving. However DMI decreased as the buffaloes approached near to calving. The possible reason for decreased DMI near calving is all buffaloes irrespective of their group were in stressed. This decreased DMI 
near calving further give research opportunity to overcome calving stress.

DMI 7 days before and 7 days after calving was 9.34, 9.86; 9.68 and $10.20 \mathrm{~kg} / \mathrm{d}$ in control and treatment group respectively. Similarly no significant $(\mathrm{P}>0.05)$ difference was observed in DMI 7 days after calving between the group. However DMI 7 days after calving became stable and stop to decrease which indicate that calving stress is over in both the groups. DMI start to increase after 7 days of calving and increased in both the groups. After 21 days of calving DMI was significantly higher $(\mathrm{P}<0.05)$ in treatment group where anion salt were fed before calving and cation salt were fed after calving. DMI from green fodder was significantly $(\mathrm{P}<0.01)$ higher in treatment group than the control in cation anion supplemented group.

Dry matter intake per $100 \mathrm{~kg}$ body weight was similar in both groups from 21days before calving to 7 days after calving but treated buffaloes showed significant increase $(\mathrm{P}<0.05)$ in dry matter intake per $100 \mathrm{~kg}$ body weight at 21 days after calving. Similar result was observed by Senthil Kumar and Kaur (2005) in cows when fed anionic salt before calving. Figure 1 shows the DMI $(\mathrm{kg} / \mathrm{d})$ during the transition period from different source as well as total (Table 7 and 8 ).

Table.1 Method to calculate mEq of a diet

\begin{tabular}{|c|c|c|c|}
\hline Mineral & Conversion Factor & \% in feed dry matter & $\begin{array}{c}\mathrm{mEq} / \mathrm{kg} \\
\text { FeedDM }\end{array}$ \\
\hline Sodium & 435 & 0.04 & +17 \\
\hline Potassium & 256 & 1.74 & +446 \\
\hline Chlorine & 282 & 0.45 & -126 \\
\hline Sulphur & 624 & 0.23 & -144 \\
\hline
\end{tabular}

$\mathrm{mEq} / \mathrm{kg}$ feed $\mathrm{DM}=\%$ in feed dry matter $\times$ Conversion Factor

$\mathrm{DCAD}=[(\mathrm{Na}+\mathrm{K})-(\mathrm{Cl}+\mathrm{S})]$

Table.2 Ingredients composition of Conc. Mix given before calving and its mEq status

\begin{tabular}{|c|c|c|c|c|c|c|c|}
\hline $\begin{array}{l}\text { S. } \\
\text { N. }\end{array}$ & Ingredients & Parts & $\mathrm{Na}^{+1}$ & $\mathrm{~K}^{+1}$ & $\mathrm{Cl}^{-1}$ & $\mathrm{~S}^{-2}$ & $\begin{array}{l}\text { DCAD } \\
(\mathrm{mEq})\end{array}$ \\
\hline 1 & Wheat & 13 & 204.15 & 1562.42 & 420.14 & 1171.37 & 175.06 \\
\hline 2 & Barley & 13 & 102.07 & 161.97 & 430.11 & 1172.90 & -1338.97 \\
\hline 3 & Maize & 14 & 54.96 & 1326.16 & 285.05 & 266.28 & 829.79 \\
\hline 4 & Mustard cake & 35 & 687.03 & 7277.76 & 712.61 & 3847.91 & 3404.27 \\
\hline 5 & WB & 22 & 172.74 & 4676.25 & 991.16 & 3152.1 & 705.73 \\
\hline 6 & MM & 2 & 0.00 & 0.00 & 0.00 & 39.43 & -39.43 \\
\hline 7 & Salt & 1 & 17108.55 & 0.00 & 17106.12 & 0.00 & 2.43 \\
\hline & Total & 100 & 18329.5 & 15004.56 & 19945.19 & 9650.05 & 3738.88 \\
\hline & & \multicolumn{2}{|c|}{ DCAD $\mathrm{mEq} / \mathrm{kg}$} & \multicolumn{4}{|c|}{37.39} \\
\hline & & \multicolumn{6}{|c|}{ DCAD (mEq )On DM basis } \\
\hline & & \multicolumn{6}{|c|}{$\begin{array}{l}4142.80 \mathrm{mEq} \text { on } \mathrm{DM} \text { basis } \\
41.43 \mathrm{mEq} / \mathrm{kgDM} \text { basis }\end{array}$} \\
\hline & & \multicolumn{6}{|c|}{$\begin{array}{l}\mathrm{mEq} \text { supplementation by } 90 \text { gram anion supplementation }=-749.16 \\
\mathrm{mEq} / \text { animal/day by supplementing } 90.00 \text { gram of anion salt }\end{array}$} \\
\hline
\end{tabular}


Table.3 mEq in silage, green and wheat straw on fresh as well as DM basis

\begin{tabular}{|c|l|c|c|c|c|c|}
\hline S.N. & Ingredients & $\mathrm{Na}^{+1}$ & $\mathrm{~K}^{+1}$ & $\mathrm{Cl}^{-1}$ & $\mathrm{~S}^{-2}$ & $\mathrm{mEq}$ \\
\hline $\mathbf{1}$ & Silage fresh basis/kg & 5.66 & 69.22 & 35.37 & 21.97 & 17.54 \\
\hline $\mathbf{2}$ & Silage/ $\mathrm{kg}$ DM basis & 21.79 & 266.50 & 136.18 & 84.59 & 67.52 \\
\hline $\mathbf{3}$ & Green fresh basis/kg & 4.83 & 59.16 & 32.47 & 19.19 & 12.33 \\
\hline $\mathbf{4}$ & Green $/ \mathrm{kg}$ DM basis & 21.74 & 266.22 & 146.12 & 86.36 & 55.18 \\
\hline $\mathbf{5}$ & WS fresh basis & 31.64 & 353.75 & 189.93 & 117.94 & 77.52 \\
\hline $\mathbf{6}$ & WS $/ \mathrm{kgDM}$ basis & 34.8 & 389.12 & 208.92 & 129.73 & 85.27 \\
\hline
\end{tabular}

Table.4 Ingredients composition of Conc. Mix given after calving and its $\mathrm{mEq}$ status

\begin{tabular}{|c|c|c|c|c|c|c|c|}
\hline S. No. & Ingredients & Parts & $\mathrm{Na}^{+1}$ & $\mathrm{~K}^{+1}$ & $\mathrm{Cl}^{-1}$ & $\mathrm{~S}^{-2}$ & DCAD (mEq) \\
\hline 1 & Wheat & 13 & 204.15 & 1562.42 & 420.14 & 1171.37 & 175.06 \\
\hline 2 & Barley & 14 & 102.07 & 161.97 & 430.11 & 1172.90 & -1338.97 \\
\hline 3 & Maize & 13 & 54.96 & 1326.16 & 285.05 & 266.28 & 829.79 \\
\hline 4 & Mustard cake & 5 & 98.15 & 1039.68 & 101.80 & 506.84 & 529.19 \\
\hline 5 & Cotton seed cake & 30 & 353.33 & 7624.32 & 611.00 & 3693.03 & 3673.62 \\
\hline 6 & WB & 22 & 172.74 & 4676.25 & 991.16 & 2849.60 & 1008.23 \\
\hline 7 & MM & 2 & 0.00 & 0.00 & 0.00 & 39.43 & -39.43 \\
\hline 8 & Salt & 1 & 17108.55 & 0.00 & 17106.12 & 0.00 & 2.43 \\
\hline & Total & 100 & & & & & 4839.92 \\
\hline & & \multicolumn{2}{|c|}{ DCAD $(\mathrm{mEq} / \mathrm{Kg})$} & \multicolumn{4}{|c|}{48.40} \\
\hline & & \multicolumn{6}{|c|}{ DCAD ( $\mathrm{mEq}$ ) on DM basis } \\
\hline & & \multicolumn{6}{|c|}{$\begin{array}{l}5362.79 \text { on DM basis } \\
53.62 / \mathrm{kg} \text { DM basis }\end{array}$} \\
\hline & & \multicolumn{6}{|c|}{ 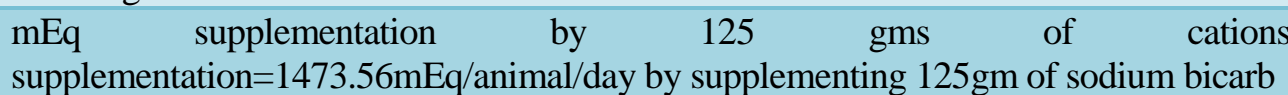 } \\
\hline
\end{tabular}

Table.5 Grouping of buffaloes on the basis of milk yield

\begin{tabular}{|c|c|c|c|c|}
\hline S.NO. & No. & $\begin{array}{l}305 \text { D milk yield } \\
\text { (Control) }\end{array}$ & No. & $\begin{array}{l}305 \text { D milk yield } \\
\text { (Treatment) }\end{array}$ \\
\hline 1 & 4219 & 3391 & 4367 & 3366 \\
\hline 2 & 4089 & 3036 & 4251 & 3156 \\
\hline 3 & 4218 & 3006 & 4197 & 2854 \\
\hline 4 & 4479 & 2834 & 4234 & 2756 \\
\hline 5 & 3546 & 2703 & 4420 & 2547 \\
\hline 6 & 4448 & 2575 & 4602 & 2261 \\
\hline 7 & 4421 & 2428 & 4400 & 2507 \\
\hline 8 & 4545 & 2427 & 4561 & 2370 \\
\hline 9 & 4445 & 2261 & 4285 & 2316 \\
\hline 10 & 4117 & 1633 & 4419 & 2164 \\
\hline Total & & 26294 & & 26297 \\
\hline Avg & & $2629.4 \pm 154.43$ & & $2629.7 \pm 125.87$ \\
\hline
\end{tabular}


Table.6 Net daily $\mathrm{mEq}$ intake of buffaloes during the transition period in different group

\begin{tabular}{|c|c|c|c|}
\hline Days & Feed & $\begin{array}{l}\text { Control } \\
\mathrm{mEq} \mathrm{SE}\end{array}$ & $\begin{array}{l}\text { Treatment } \\
\mathrm{mEq} \pm \mathrm{SE}\end{array}$ \\
\hline \multirow[t]{7}{*}{-21 days of Calving } & Total mEq & $729.79 \pm 36.01$ & $713.37 \pm 27.61$ \\
\hline & Concentrate & $134.98 \pm 0.00$ & $134.98 \pm 0.00$ \\
\hline & Green & $345.52 \pm 11.13$ & $301.21 \pm 29.21$ \\
\hline & WS & $249.29 \pm 29.96$ & $277.18 \pm 15.40$ \\
\hline & Supple. $\mathrm{mEq}$ & 0.00 & -749.16 \\
\hline & Net mEq & $729.79 \pm 36.01$ & $-35.79 \pm 27.61$ \\
\hline & Body Wt & $569.34 \pm 12.90$ & $565.37 \pm 11.12$ \\
\hline \multirow[t]{7}{*}{-7 day of Calving } & Total mEq & $571.19 \pm 18.07$ & $600.34 \pm 19.81$ \\
\hline & Concentrate & $232.03 \pm 0.00$ & $232.03 \pm 0.00$ \\
\hline & Green & $277.18 \pm 11.91$ & $276.04 \pm 12.00$ \\
\hline & WS & $61.97 \pm 7.81$ & $92.26 \pm 11.24$ \\
\hline & Supple mEq & 0.00 & -749.16 \\
\hline & Net $\mathrm{mEq}$ & $571.19 \pm 18.07$ & $-148.82 \pm 19.81$ \\
\hline & Body Wt & $576.20 \pm 12.86$ & $572.32 \pm 11.16$ \\
\hline \multirow{7}{*}{7 day of calving } & Total mEq & $570.15 \pm 8.51$ & $589.07 \pm 5.44$ \\
\hline & Concentrate & $359.78 \pm 0.00$ & $359.78 \pm 0.00$ \\
\hline & Green & $16954 \pm 9.30$ & $187.45 \pm 6.01$ \\
\hline & WS & $40.82 \pm 4.24$ & $41.83 \pm 4.31$ \\
\hline & Supple mEq & 0.00 & +1473.56 \\
\hline & Net mEq & $570.15 \pm 8.51$ & $2062.63 \pm 5.44$ \\
\hline & Body Wt & $531.25 \pm 14.14$ & $528.79 \pm 13.62$ \\
\hline \multirow[t]{7}{*}{21 days of Calving } & Total mEq & $669.24 \pm 7.84$ & $759.77 \pm 28.68$ \\
\hline & Concentrate & $411.18 \pm 0.00$ & $411.18 \pm 0.00$ \\
\hline & Green & $213.12 \pm 6.34$ & $246.10 \pm 5.33$ \\
\hline & WS & $44.93 \pm 5.57$ & $102.49 \pm 25.32$ \\
\hline & Body Wt & $492.11 \pm 14.21$ & $487.16 \pm 12.53$ \\
\hline & Supple mEq & 0.00 & +1473.56 \\
\hline & Net $m E q$ & $669.24 \pm 7.84$ & $2233.33 \pm 28.68$ \\
\hline
\end{tabular}


Table.7 Effect of cation anion feeding on dry matter intake during transition feeding

\begin{tabular}{|c|c|c|c|}
\hline Days & Feed & $\begin{array}{c}\text { Control } \\
\mathrm{DMI}(\mathrm{Kg}) \pm \mathrm{SE}\end{array}$ & $\begin{array}{c}\text { Treatment } \\
\mathrm{DMI}(\mathrm{Kg}) \pm \mathrm{SE}\end{array}$ \\
\hline \multirow[t]{6}{*}{-21 days of Calving } & Total DMI & $11.65 \pm 0.44$ & $11.32 \pm 0.40$ \\
\hline & Concentrate & $3.61 \pm 0.00$ & $3.61 \pm 0.00$ \\
\hline & Green & $5.11 \pm 0.16$ & $4.46 \pm 0.43$ \\
\hline & WS & $2.92 \pm 0.35$ & $3.25 \pm 0.18$ \\
\hline & Body Wt. & $569.34 \pm 12.90$ & $565.37 \pm 11.12$ \\
\hline & $\mathrm{mEq} / 100 \mathrm{gmDM}$ & 6.26 & -0.32 \\
\hline \multirow[t]{6}{*}{-7 day of Calving } & Total DMI & $9.34 \pm 0.24$ & $9.68 \pm 0.26$ \\
\hline & Concentrate & $4.51 \pm 0.00$ & $4.51 \pm 0.00$ \\
\hline & Green & $4.10 \pm 0.17$ & $4.09 \pm 0.17$ \\
\hline & WS & $0.72 \pm 0.09$ & $1.08 \pm 0.13$ \\
\hline & Body Wt. & $576.20 \pm 12.86$ & $572.32 \pm 11.16$ \\
\hline & $\mathrm{mEq} / 100 \mathrm{gmDM}$ & 6.11 & -1.54 \\
\hline \multirow[t]{6}{*}{7 days of calving } & Total DMI & $9.86 \pm 0.15$ & $10.20 \pm 0.09$ \\
\hline & Concentrate & $6.32 \pm 0.00$ & $6.32 \pm 0.00$ \\
\hline & Green & $3.070 .16 \pm$ & $3.39 \pm 0.10$ \\
\hline & WS & $0.47 \pm 0.05$ & $0.49 \pm 0.05$ \\
\hline & Body Wt. & $531.25 \pm 14.14$ & $528.79 \pm 13.62$ \\
\hline & $\mathrm{mEq} / 100 \mathrm{gmDM}$ & 5.78 & 20.22 \\
\hline \multirow[t]{6}{*}{21 days of Calving } & Total DMI* & $11.60 \pm 0.12^{\mathrm{a}}$ & $12.88 \pm 0.36^{\mathbf{b}}$ \\
\hline & Concentrate & $7.22 \pm 0.00$ & $7.22 \pm 0.00$ \\
\hline & Green $^{* *}$ & $3.86 \pm 0.11^{\mathrm{a}}$ & $4.45 \pm 0.09^{\mathbf{b}}$ \\
\hline & $\mathrm{WS}^{*}$ & $0.52 \pm 0.06^{\mathrm{a}}$ & $1.20 \pm 0.29^{\mathbf{b}}$ \\
\hline & Body Wt. & $492.11 \pm 14.21$ & $487.16 \pm 12.53$ \\
\hline & $\mathrm{mEq} / 100 \mathrm{gmDM}$ & 5.77 & 17.34 \\
\hline
\end{tabular}

*Superscript bearing different letters in a row differ significantly $(\mathrm{p}<0.05)$

**Superscript bearing different letters in a row differ significantly $(\mathrm{p}<0.001)$ 
Table.8 DMI/ $100 \mathrm{~kg}$ body weight in buffaloes during the transition period

\begin{tabular}{|c|c|c|c|}
\hline Days & Feed & $\begin{array}{c}\text { Control } \\
\mathrm{DMI}(\mathrm{Kg}) \pm \mathrm{SE}\end{array}$ & $\begin{array}{c}\text { Treatment } \\
\text { DMI }(\mathrm{Kg}) \pm \mathrm{SE}\end{array}$ \\
\hline \multirow[t]{4}{*}{-21 days of Calving } & Total DMI & $2.05 \pm 0.084$ & $2.0 \pm 0.068$ \\
\hline & Concentrate & $0.64 \pm 0.015$ & $0.64 \pm 0.12$ \\
\hline & Green & $0.90 \pm 0.02$ & $0.79 \pm 0.07$ \\
\hline & WS & $0.52 \pm 0.06$ & $0.58 \pm 0.03$ \\
\hline \multirow[t]{4}{*}{-7 day of Calving } & Total DMI & $1.65 \pm 0.04$ & $1.68 \pm 0.046$ \\
\hline & Concentrate & $0.79 \pm 0.019$ & $0.79 \pm 0.015$ \\
\hline & Green & $0.71 \pm 0.027$ & $0.72 \pm 0.03$ \\
\hline & WS & $0.15 \pm 0.014$ & $0.17 \pm 0.017$ \\
\hline \multirow[t]{4}{*}{7 days of calving } & Total DMI & $1.87 \pm 0.044$ & $1.94 \pm 0.045$ \\
\hline & Concentrate & $1.20 \pm 0.034$ & $1.20 \pm 0.03$ \\
\hline & Green & $0.58 \pm 0.026$ & $0.64 \pm 0.019$ \\
\hline & WS & $0.09 \pm 0.01$ & $0.09 \pm 0.010$ \\
\hline \multirow[t]{4}{*}{21 days of Calving } & Total DMI* & $2.37 \pm 0.60^{\mathrm{a}}$ & $2.65 \pm 0.055^{b}$ \\
\hline & Concentrate & $1.48 \pm 0.046$ & $1.49 \pm 0.039$ \\
\hline & Green** & $0.79 \pm 0.02^{\mathrm{a}}$ & $0.92 \pm 0.024^{\mathbf{b}}$ \\
\hline & WS* & $0.11 \pm 0.013^{\mathrm{a}}$ & $0.24 \pm 0.05^{b}$ \\
\hline
\end{tabular}

*Superscript bearing different letters in a row differ significantly $(\mathrm{p}<0.05)$

**Superscript bearing different letters in a row differ significantly $(\mathrm{p}<0.001)$

Fig.1 Effect of cation anion feeding on Feed intake (DMB)

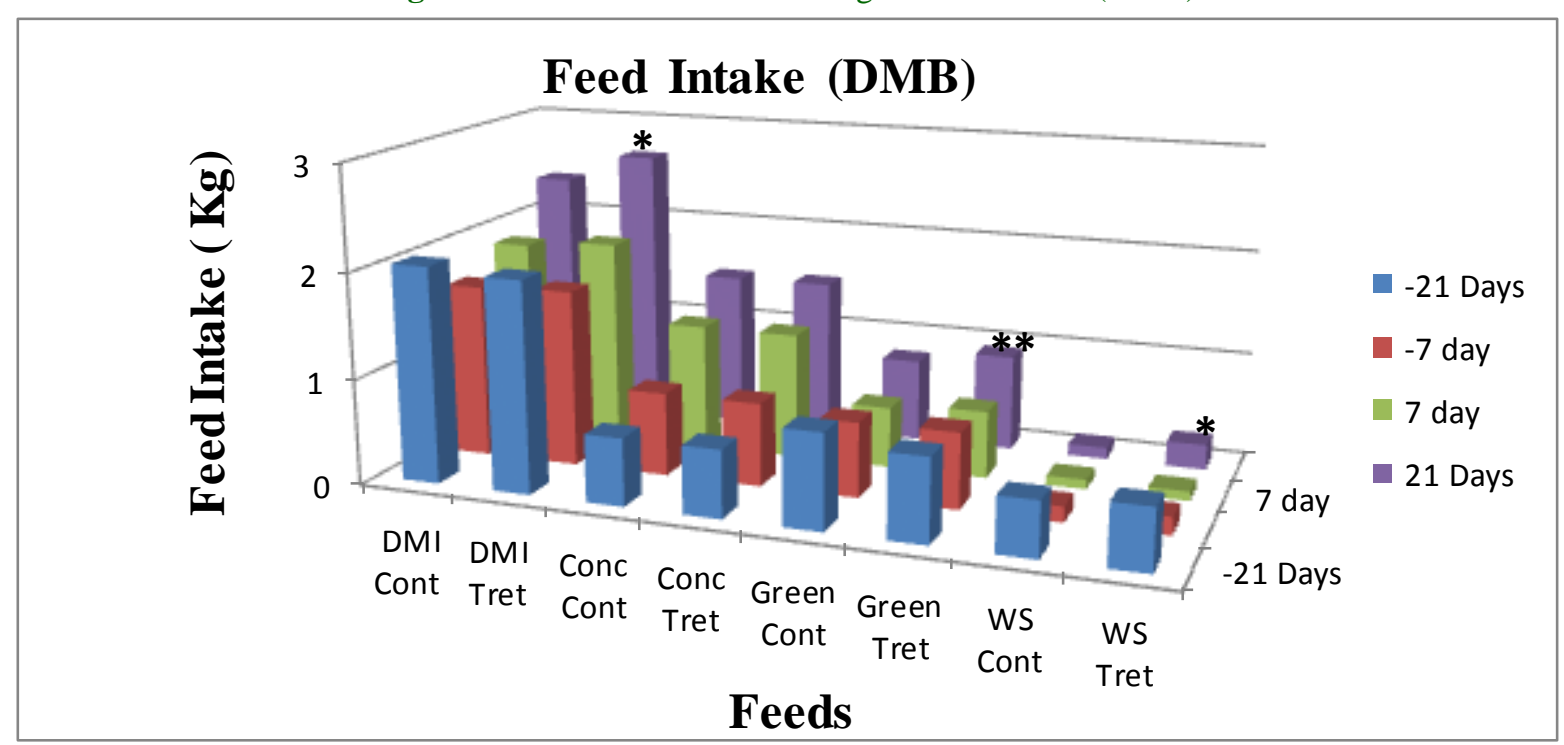

$\left(* \mathrm{P}<0.05,{ }^{*} \mathrm{P}<0.001\right)$ 
Tucker et al., (1988) reported that a DCAD $[(\mathrm{Na}+\mathrm{K})-\mathrm{Cl}]$ of $0,+10$, and $+20 \mathrm{mEq} / 100 \mathrm{~g}$ of DM increased DMI of lactating dairy cows compared with cows consuming rations with DCAD values of $-10 \mathrm{mEq} / 100 \mathrm{~g}$ of $\mathrm{DM}$ which is in agreement to our present study in which post calving cation supplementation was given. An optimum DCAD $[(\mathrm{Na}+\mathrm{K}+$ $0.15 \mathrm{Ca}+0.15 \mathrm{Mg})-(\mathrm{Cl}+0.60 \mathrm{~S}+0.50 \mathrm{P})]$ range of +15 to $+20 \mathrm{mEq} / 100 \mathrm{~g}$ of $\mathrm{DM}$ (Roche et al., 2000) has been found that positively affect DMI in dairy cows (Sanchez et al., 1994; Roche et al., 2005). An increase in nutrient intake with positive DCAD diet has also been reported by Jackson et al., (1992) and Shahzad et al., (2007, 2008a). Hu et al., (2007) in a review of 21 experiments, reported peak DMI at DCAD values of 40 $\mathrm{mEq} / 100 \mathrm{~g}$ of DM and an overall quadratic increase in DMI of dairy cow diets with increasing DCAD. The increase in DM intake in calves of W2 group fed high DCAD diets might be due to increased rumen $\mathrm{pH}$ (Sharif et al., 2009, 2010) that makes the ruminal environment alkaline, which is a pre-requisite for optimum ruminal microbial activity. The effect of DCAD on DMI has a direct effect on the supply of nutrients for maintenance, growth, gestation, and lactation.

The periparturient disease conditions are associated with decreased dry matter intake (DMI), and feed intake is a critical determinant of health and productivity in the dry period. Feed intake and nutrient density of the diet determine the availability of nutrients to the cow and rapidly developing fetus.

Grant and Albright (1996) reviewed the feeding behavior and management factors during the transition period for dairy cattle and found that feed intake decreased by up to $30 \%$ during the week before calving. Factors that influence feed intake include social dominance, indigestibility of the diet, access to feed and the palatability of the feed
(Grantand Albright, 1996). Cows are comparatively insensitive to insulin near the calving and have relatively low concentrations of insulin at this time helping maintain a constant blood glucose level despite declining feed intake in the last week or so before calving. This is because utilization of glucose by tissues decreases, while utilization of energy sources derived from lipids by muscle increases, sparing glucose. This signals an increase in the rate of mobilization of body fat stores to support lactation. This has implications for health and fertility as excessive mobilization of tissue increases the risk of diseases such as ketosis, uterine infections and fatty liver. It has been suggested that control of feed intake is mediated in part through oxidation of propionate in the liver, resulting in greater satiety (Allen et al., 2009). Consequently, fats and less fermentable carbohydrates sources may be important to use in early lactation.

Cows and sheep in higher body condition scores have lower dry matter intakes after parturition (Garnsworthy and Topps, 1982) and (Cowan et al., 1980) and lower dry matter intake has been noted immediately after calving (Lean et al., 1994) and before calving (Lean et al., unpublished) for cows with clinical ketosis. Heavily conditioned cattle can have markedly lower dry matter intakes and this is noted especially in cattle with greater than BCS $>3.5 / 5$ (greater than six on the one to eight scale). More obese animals are at higher risk of milk fever (Stockdale, 2007).

The effect of greater dry matter intake was shown by the force feeding through a ruminal fistula of periparturient cows (Bertics et al., 1992). Cows that taken more feed had less hepatic lipid accumulation and more milk production after calving. The higher milk production resulted from greater post-calving feed intake and a highly significant positive 
correlation between pre- and post-calving feed intake was identified (Bertics et al,. 1992).

\section{References}

Allen, M. S., Bradford, B. J., and Oba, M. (2009). Board-Invited Review: The hepatic oxidation theory of the control of feed intake and its application to ruminants. Journal of animal science, 87(10), 3317-3334.

Bertics, S. J., Grummer, R. R., CadornigaValino, C., and Stoddard, E. E. (1992). Effect of prepartum dry matter intake on liver triglyceride concentration and early lactation. Journal of dairy science, 75(7), 1914-1922.

Cowan, R. T., Robinson, J. J., McDonald, I., and Smart, R. (1980). Effects of body fatness at lambing and diet in lactation on body tissue loss, feed intake and milk yield of ewes in early lactation. The Journal of Agricultural Science, 95(3), 497-514.

Garnsworthy, P. C., and Topps, J. H. (1982). The effect of body condition of dairy cows at calving on their food intake and performance when given complete diets. Animal Science, 35(1), 113-119.

Grant, R. J., and Albright, J. L. (1996). Feeding behavior and management factors during the transition period in dairy cattle. Journal of animal Science, 73(9), 2791-2803

$\mathrm{Hu}$, W., Kung Jr, L., and Murphy, M. R. (2007).Relationships between dry matter intake and acid-base status of lactating dairy cows as manipulated by dietary cation-anion difference. Animal feed science and technology, 136(3-4), 216-225.

Lean, I. J., Bruss, M. L., Troutt, H. F., Galland, J. C., Farver, T. B., Rostami, J., ... and Weaver, L. D. (1994). Bovine ketosis and somatotrophin: risk factors for ketosis and effects of ketosis on health and production. Research in veterinary science, 57(2), 200-209.

Roche, J. R., Dalley, D., Moate, P., Grainger, C., Hannah, M., O'Mara, F., and Rath, M. (2000). Variations in the dietary cation-anion difference and the acidbase balance of dairy cows on a pasture-based diet in south-eastern Australia. Grass and Forage Science, 55(1), 26-36.

Sanchez, W. K. (1994). Cation-anion concepts for lactating dairy rations.Cation-anion applications for lactating dairy cattle.In Proceedings of Mallinckrodt Feed Ingredients Conference. Rochester, NY, 1994 (pp. 1-13).

Senthil Kumar, R., and Kaur, H. (2005). Effect of prepartum feeding of anionic and cationic diets on plasma macro minerals and vitamin D homeostasis in crossbred cows. Indian Journal of Animal Nutrition, 22(4), 214-220.

Shahzad, M. A., and Sarwar, M. (2007). Nutrient intake, acid base status and growth performance of growing male buffalo calves fed varying level of dietary cation anion difference. Livestock Science, 111(1), 136-143.

Shahzad, M. A., and Sarwar, M. (2008a). Influence of varying dietary cation anion difference on serum minerals, mineral balance and hypocalcemia in Nili Ravi buffaloes. Livestock Science, 113(1), 52-61.

Sharif, M., Shahzad, M. A., and Sarwar, M. (2010). Influence of varying levels of dietary cation anion difference on ruminal characteristics, nitrogen metabolism and in situ digestion kinetics in buffalo bulls. Animal science journal, 81(6), 657-665.

Sharif, M., Shahzad, M. A., Nisa, M., and 
Sarwar, M. (2009, October). Nutrients intake and ovarian profile as affected by cationic anionic diets in nili-ravi buffaloes during winter. in Proceedings of 6th Asian Buffalo Congress held on (Vol. 27, p. 30).

Stockdale, C. R. (2007). Effects of body condition and diet in late gestation on the subsequent health and performance of dairy cows. Australian Journal of Experimental Agriculture, 47(5), 495-501.

Tucker, W. B., Harrison, G. A., and Hemken, R. W. (1988).Influence of Dietary Cation-Anion Balance on Milk, Blood, Urine, and Rumen Fluid in Lactating Dairy Cattle1. Journal of Dairy Science, 71(2), 346-354.

\section{How to cite this article:}

Ram Narayan Patel, P.C. Lailer, Pramod Kumar Soni, Vipin, Poonam Patel. 2018. Effect of Supplementing Cation Anion Salt on Feed Intake During Transition Period in Buffaloes. Int.J.Curr.Microbiol.App.Sci. 7(07): 2340-2350. doi: https://doi.org/10.20546/ijcmas.2018.707.272 